\title{
Hominin Femur finding from Banjarejo: Its morphological character and taxonomical position
}

\author{
Sofwan Noerwidi ${ }^{1}$, Rusyad Adi Suriyanto ${ }^{2}$, Ashwin Prayudi ${ }^{2}$ and Harry Widianto ${ }^{1}$ \\ ${ }^{1}$ Balai Arkeologi Provinsi D.I. Yogyakarta, Indonesia \\ ${ }^{2}$ Laboratory of Bioanthropology and Paleoanthropology, Universitas Gadjah Mada
}

\begin{abstract}
Recently, Banjarejo became an important prehistoric site for Quaternary research because of its significant faunal and hominin remains. This study aims to describe a new finding of the hominin femur specimen from the site and its taxonomical position in human evolution. The specimen was identified by morphological and metric descriptions of the external feature of the femur. Then, comparative study to Homo erectus $(\mathrm{n}=2)$, Homo neanderthalensis $(\mathrm{n}=8)$, Homo heidelbergensis $(\mathrm{n}=1)$, prehistoric Homo sapiens $(\mathrm{n}=44)$, Australopithecus africanus $(\mathrm{n}=1)$, Paranthropus robustus $(\mathrm{n}=2)$, also nonhuman primate including Pongo $(\mathrm{n}=1)$, Macaca $(\mathrm{n}=1)$ and Gibbon $(\mathrm{n}=1)$ using bivariate and multivariate statistical analysis presented the specimen in the evolutionary perspective. This study shows the morphological and metric character of Banjarejo specimen located between Homo erectus and prehistoric Homo sapiens population sample. Further study should be addressed to investigate the cultural and chronological context of the hominin specimen.
\end{abstract}

Keywords: hominin, human evolution, Banjarejo, Quaternary

\footnotetext{
Copyright (C2021. FOSI. All rights reserved.

A Special Publication of abstracts and extended abstracts from the conference in honor of the retirement of Prof. Yahdi Zaim, IPU (22-23 March 2021).
}

DOI:10.51835/bsed.2021.47.3.350 


\section{INTRODUCTION}

Banjarejo is administratively located at Gabus District on the eastern part of Grobogan Regency, Central Java. The physiographical condition of Banjarejo is a region located in an elongated shape of the Randublatung Depression, which covers Purwodadi, Cepu, and Bojonegoro (van Bemmelen, 1949). The depression is located between two anticlines mountains of Kendeng to the south and the Rembang Zone of Northern Mountain. Lowlands at around $20 \mathrm{~m}$ above sea level dominated the morphological condition of the depression, with Lusi River and its ancient terraces located inside. Hills with up to $280 \mathrm{~m}$ asl altitude dominate the northern side of Randublatung Depression, which is part of the karstic hills of Rembang Zone, and the southern side of the depression, which is part of Kendeng Mountain (Fathoni, 2016). The synclinal zone of Randublatung Depression has formed caused by subsidence activity part of isostatic equilibrium of the region through the tectonic subduction process during the Late Tertiary (Datun et al., 1996).

In 2015, locals of Banjarejo site found an almost complete Bubalus paleokarabau cranium at the terrace of Lusi River and reported to the author. Since then, the recognition of quaternary paleontological potentials of the site began. BPSMP Sangiran identified the fossils and artifacts and conducted an exploration excavation at Ngrunut locality in 2016 (Rahmat, 2016). The excavation was continued to 2018 when they found an accumulation of 872 fossils at the Kuwojo locality, which dominantly by Proboscidean fauna (Widiyanta, 2018). There is identification of other faunal remains in this research, including Bovidae, Cervidae, Gavialis, Crocodylus, Gastropoda, and catfish. The research placed the site's chronological position in the upper part of the Lidah Formation around the Mid Pleistocene (Widiyanta, 2020). They also identify paleoenvironment alteration of the depression from a condition near the shoreline (wave zone) to a terrestrial condition as savanna and open forest.

An important recent discovery at Banjarejo site is a fragment of hominin femur from the Lusi River terrace in 2019 and conserved in the BPSMP Sangiran. There is no analysis work conducted on this first hominin specimen from the site. Consequently, the identity of this important specimen is still unknown. This study aims to identify hominin findings from the site, also its taxonomical position and implication to the history of human evolution in Java.

\section{METHODOLOGY}

\section{Material}

a.Main Material: The primary material of this study is a fragment of proximal diaphysis of hominin femur from Banjarejo, found by Pak Modin (Budi Setyo Utomo) a conservation activist of the site.

b.Comparison Material: The materials used for comparison 
includes Homo erectus $(\mathrm{n}=2)$

\begin{tabular}{lllr}
\hline No & Site / Origin & \multicolumn{1}{c}{ Taxa } & Total \\
\hline 1 & Taforalt & Homo sapiens & 39 \\
\hline 2 & Gilimanuk & Homo sapiens & 2 \\
\hline 3 & Java & Homo sapiens & 3 \\
\hline 4 & Trinil & Homo erectus & 2 \\
\hline 5 & Krapina & Homo neanderthalensis & 5 \\
\hline 6 & Spy & Homo neanderthalensis & 3 \\
\hline 7 & Arago & Homo heidelbergensis & 1 \\
\hline 8 & Swartkrans & Paranthropus robustus & 2 \\
\hline 9 & Swartkrans & Australopithecus africamus & 1 \\
\hline 10 & Sumatra & Pongo & 2 \\
\hline 11 & SE Asia & Gibbon & 1 \\
\hline 12 & Java & Macaca & 1 \\
\hline
\end{tabular}

Table 1. Site or origin sample used in this study

from Trinil, Homo neanderthalensis $(n=8)$ from Krapina and Spy, Homo heidelbergensis $(n=1)$ from Arago, prehistoric Homo sapiens $(n=44)$ from Taforalt, Gilimanuk, and Java, Australopithecus africanus $(\mathrm{n}=1)$, and Paranthropus robustus $(n=2) \quad$ from Swartkrans, also non-human primate including Pongo $(n=1)$ from Sumatra, Macaca $(n=1)$ from Java and Gibbon $(n=1)$ from unknown precise location

\begin{tabular}{lll}
\hline No & Abbreviation & \multicolumn{1}{c}{ Definition } \\
\hline 1 & M15 & Vertical diameter of column femoralis \\
\hline 2 & M16 & Sagittal diameter of column femoralis \\
\hline 3 & M17 & Maximum circumference of column femoralis \\
\hline 4 & M18 & Vertical diameter of caput femoralis \\
\hline 5 & M19 & Transversal / sagittal diameter of the caput femoralis \\
\hline 6 & M20 & Maximum circumference of the caput femoralis \\
\hline
\end{tabular}

Table 2. Abbreviation and definition measurement on proximal epiphysis of femur of Southeast Asia (Table 1).

$\underline{\text { Tool }}$

a.Caliper, used for measuring the diameter aspects of the femur

b.Tape meter, used for measuring the circumference aspects of the femur

\section{Method}

The analysis was conducted to determine the taxonomic identity of the femoral head of Banjarejo site by comparing morphological and morphometric characters to populations of Homo sapiens, Homo erectus, Homo heidelbergensis, Homo neanderthalensis, Paranthropus robustus, Australopithecus africanus,

\begin{tabular}{ll}
\hline No & \multicolumn{1}{c}{ Variabel } \\
\hline 1 & Diameter antero-posterior $70 \%$ \\
\hline 2 & Diameter medio-lateral $70 \%$ \\
\hline 3 & Tebal cortical $70 \%$ \\
\hline 4 & Minimum circumference $70 \%$ \\
\hline
\end{tabular}

Table 3. Measurement variables on diaphysis of femur.

and other non-human primate groups, including Pongo, Gibbon, and Macaca.

Morphometric comparisons were carried out using measurement variables proposed by Martin and Saller (1957). The following table is the definition of the measurement variable on proximal epiphysis of the femur (Table 2). 


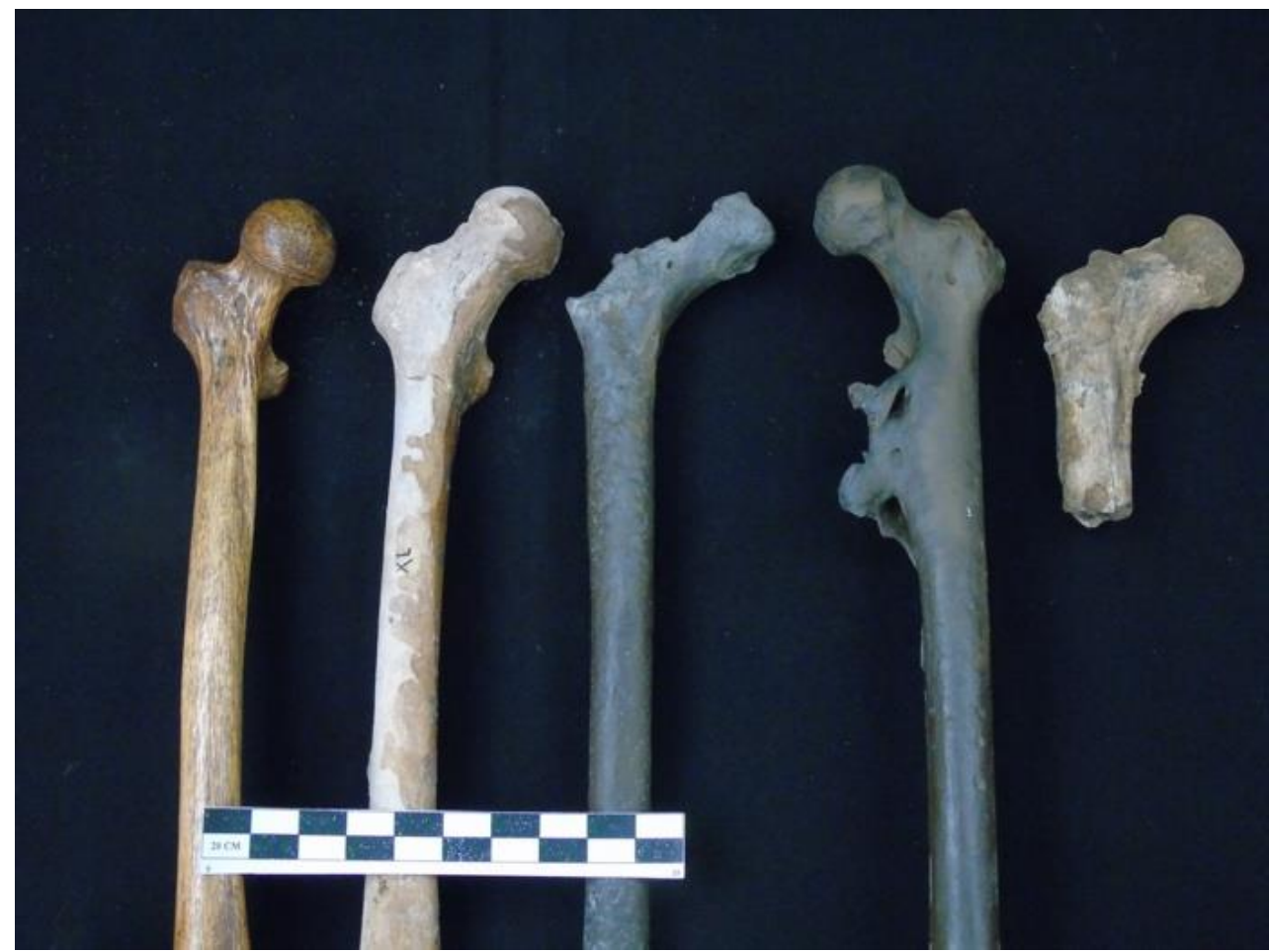

Figure 1. Comparison of femur: 1. Modern Homo sapiens (original), 2. Prehistoric Homo sapiens from Gilimanuk (original), 3. Homo erectus Trinil 2 (replica), 4. Homo erectus Trini 1 (replica) and 5. Banjarejo hominin (original)

Measurements on the femur diaphysis of Banjarejo specimen cannot be done using the classic morphometric variables proposed by Martin and Saller (1957) due to the conservation condition of the specimens. However, several measurements could be made based on the technique proposed by Ruff (2003) on the 60\% - 80\% segment of the diaphysis, including (Table 3).

Metric comparative analysis was performed using PAST software (Paleontological Statistics) version 3.25, developed specifically for paleontological analysis (Hammer, 2018). Comparative studies conducted were including bivariate and multivariate comparisons. A bivariate comparison was performed on two related variables, such as comparing
M15 vertical diameter and M16 sagittal diameter of the femoral column on some populations using a biplot graph representation. A $60 \%$ of ellipse distribution was set to limit the population's distribution, which connects all specimens in the specific population.

Multivariate comparative analysis was conducted to compare correlated variables, such as measurements of the column and femoral head. This multivariate comparison was performed using Principal Component Analysis (PCA) for a continuous data value, with some conditions: the use of a correlation matrix because all measured variables are correlated, the separation between groups, and a technique of replacing missing data by 
calculating the mean value. The PCA biplot chart presentation also used a $60 \%$ ellipse to limit one population distribution to others.

\section{RESULTS}

Morphological Analysis: The general morphological feature of the femoral even fused with the superior head part. Thus, the femoral head is not perfectly rounded. For example, the femoral head shape, such as the latter form, is founded in Artiodactyl and Perissodactyl (France, 2009).

On the medial section of the femoral head of Banjarejo site, there were

\begin{tabular}{|c|c|c|c|c|c|c|c|c|}
\hline No & Variabel & Banjarejo & $\begin{array}{c}\text { Gilimanuk } \\
\text { LX }\end{array}$ & $\begin{array}{c}\text { Kresna } \\
11 *\end{array}$ & $\begin{array}{l}\text { Trinil } \\
\text { F II** }\end{array}$ & $\begin{array}{l}\text { Trinil } \\
\text { F III** }\end{array}$ & $\begin{array}{l}\text { Trinil } \\
\text { F IV** }\end{array}$ & $\begin{array}{l}\text { Modern } \\
\text { Human* }\end{array}$ \\
\hline 1 & $\begin{array}{l}\text { Diameter antero- } \\
\text { posterior } 70 \%\end{array}$ & 27 & 27 & 26 & 22,5 & 22,3 & 29,3 & $26-30$ \\
\hline 2 & $\begin{array}{l}\text { Diameter medio- } \\
\text { lateral } 70 \%\end{array}$ & 30 & 28 & 33 & 27 & 24,1 & 29,3 & $27-31$ \\
\hline 3 & $\begin{array}{l}\text { Tebal cortical } \\
70 \%\end{array}$ & $8-10$ & & 5-8 & & & & $5-9$ \\
\hline 4 & $\begin{array}{l}\text { Minimum } \\
\text { circumference } \\
70 \%\end{array}$ & 94 & 94 & & & & & \\
\hline
\end{tabular}

Table 4 Comparison of measurement result on diaphysis of the femur. Sources: * Puymerail et al. (2012), ** Ruff et al. (2015)

head from Banjarejo site is perfectly rounded, almost half-sphere with a long femoral column shape, allowing for some locomotion, including flexion, extension, abduction, adduction, internal rotation, and external rotation (White and Folkens, 2005). This kind of femoral shape, which supports those locomotion types, is usually shared by primates, especially human femurs (Figure 1). In comparison, animals with an anterior-posterior and limited rotation femur locomotion usually have an oval and flattened femoral head with a short femoral column, traces of fovea capitis. This anatomical trail is a small non-articular depression around the middle of the femoral head, where the ligamentum teres connects between the femoral head and the acetabulum on the os coxae.

Morphometric Analysis

- Bivariate analysis

Bivariate analysis was made based on several measurement techniques 
proposed by Ruff (2003) on the $60 \%-80 \%$ segment of the femur diaphysis in Table 4.

The results of the measurements can be used as materials for a comparative study of two variables of Banjarejo specimens with prehistoric Homo sapiens of Gilimanuk LX specimen and several Homo erectus specimens from Sangiran (Puymerail et al., 2012) and Trinil (Ruff et al., 2015) (Table 4). The following graphic resulted from the biplot matrix on anteroposterior diameter versus mediolateral diameter comparison between Banjarejo specimen to other femurs.

Based on the comparative analysis of the two measurement variables (Figure 2), the Banjarejo specimen located in the distribution slice of population distributions between Homo erectus and Homo sapiens. The anteroposterior diameter of Banjarejo specimen is slightly larger than Kresna 11, slightly smaller than Trinil F IV, but much larger than Trinil F II and Trinil F III. Then the mediolateral diameter of the specimen is slightly larger than Trinil F IV, smaller than Kresna 11, but much larger than Trinil F II and Trinil F III.

Furthermore, based on the thickness ratio of the femur cortical diaphysis, it is known that the Banjarejo specimen is slightly thicker than the Kresna 11 specimen from the Sangiran Site with a cortical thickness of between 8-10

$\mathrm{mm}$ (see Table 4). Based on a comparative study on morphology and morphometry to femur diaphysis of Kresna 11, Trinil specimens, and prehistoric Homo sapiens mentioned above, it is concluded that the femur diaphysis of the Banjarejo specimen belongs to early hominin.

- Multivariate analysis

The analysis using PCA was performed on three variables of the femoral column and head, namely, M15 (vertical diameter of column), M16 (sagittal diameter of column), M17 (column circumference), M18 (vertical diameter of caput), M19 (transverse or 

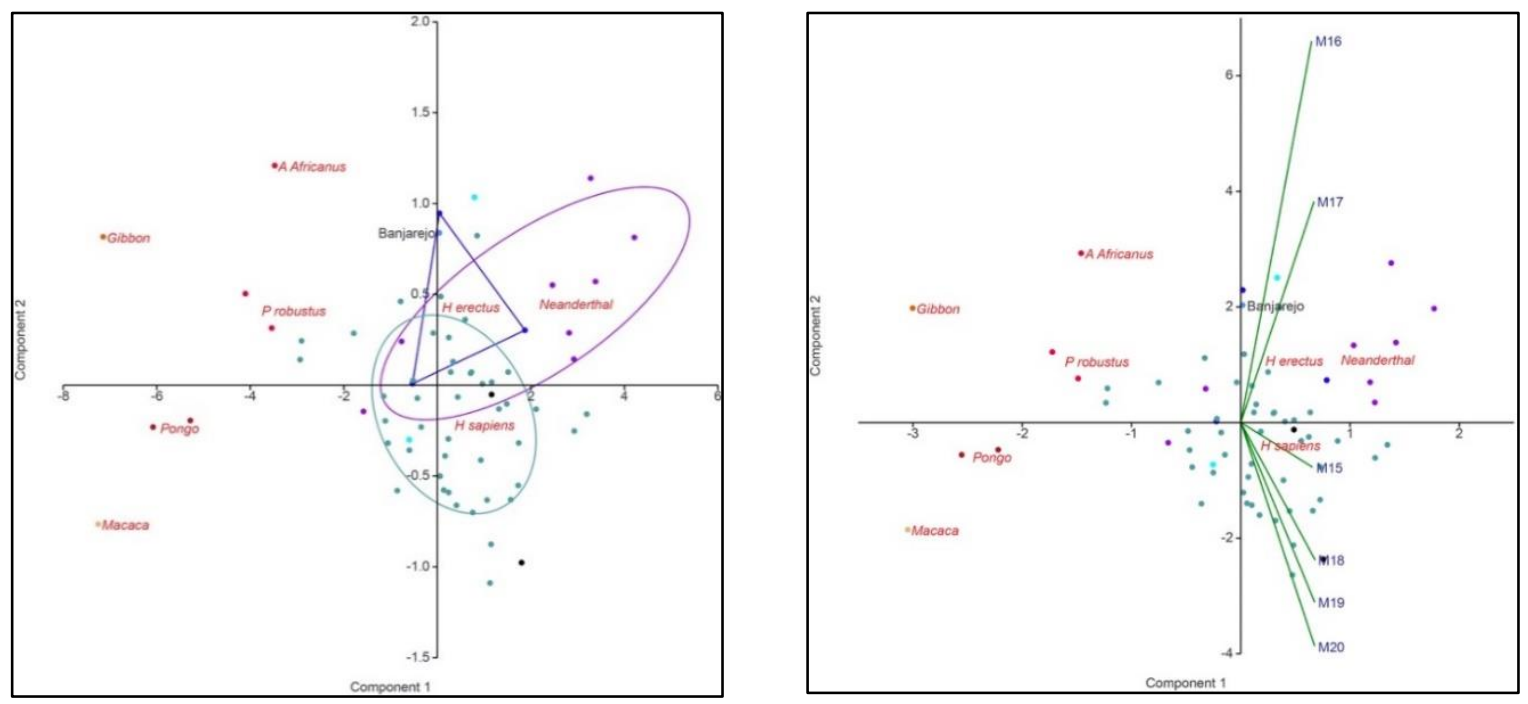

Figure 3. Biplot graphic of PCA represents component 1 vs Component 2 on femoral head and column. Left $=$ Population distribution, Right $=$ With variable representation

sagittal diameter of caput), and M20 (caput circumference).

The PCA plot graph (Figure 3) shows that the distribution of all hominin populations except Paranthropus and Australopithecus located to the right of Component 1 , meanwhile the distribution of all non-human primate populations located to the left of the component. Consequently, it could be stated that the hominin population, except Paranthropus and Australopithecus have a larger size of the femoral head compared to the nonhuman primate population. Among these hominin populations, Neanderthal has a relatively larger size of femoral head and column compared to other hominin populations. However, Homo erectus specimens are in the slice distribution between Homo sapiens and Neanderthal samples.

The figure also shows that the entire early hominin population distribution, including Homo erectus and Homo neanderthalensis, are located above Component 2. Meanwhile, the distribution of Homo sapiens population is located near the axis of the component. Therefore, it could be stated that the early hominin population has the size of M16 (vertical diameter of column) and M17 (column circumference) larger than the Homo sapiens population. Amongst the early hominin populations, Neanderthal had diverse sizes of M16 and M17, compared to the specimens from Trinil and Banjarejo, which are in proximity and tended to have larger size of M16 and M17 than the other Homo sapiens population.

\section{CONCLUSION}

This study presents the Banjarejo specimen in a distribution slice of population distribution between Homo erectus and Homo sapiens based on 
comparative analysis of two variable measurements on femur diaphysis. Based on the thickness ratio of femur cortical diaphysis, the Banjarejo specimen is slightly thicker than the Homo erectus and modern Homo sapiens specimens.

Furthermore, based on the column and femoral head morphometric analysis result, it is concluded that Banjarejo specimen generally has a matching size to early hominin populations, particularly to the Neanderthal. Specifically, the specimen has larger M16 (sagittal diameter) and M17 (column circumference) sizes compared to the Homo sapiens population mean size, but close to the Homo erectus specimen from Trinil. In conclusion, this study places the proximal epiphysis femur fragment from Banjarejo site belong to the early hominin, tentatively assigned as Homo erectus. Further study is needed to answer chronological position of the hominin by metric dating of the femur and/or its lithological context.

\section{ACKNOWLEDGEMENTS}

The authors would like to acknowledge their colleagues who support this study; Taufik Ahmad - Lurah of Banjarejo, Budi Setyo Utomo "Pak Modin" a conservation activist of Banjarejo site, Sukiato Khurniawan and the organizer who gave the opportunity for the authors to contribute to the conference. This paper is dedicated to Prof. Dr. Ir. Yahdi Zaim, DEA for his great contribution in the development of Quaternary
Prehistory studies in Indonesia in the last 40 years.

\section{REFERENCES}

Datun, M. S., Hermanto, B. and Suwarna, N., 1996. Peta Geologi Lembar Ngawi, Jawa. Pusat Penelitian dan Pengembangan Geologi.

Fathoni, M. R., 2016. Interpretasi awal geologi daerah Banjarejo dan sekitarnya: Geomorfologi, stratigrafi, dan sejarah geologi. Jurnal Sangiran, 5, 81-105.

France, D. L., 2009) Human and Nonhuman Bone Identification: a color atlas. NW: Taylor \& Francis Group. Retrieved from

\section{http://www.taylorandfrancis.com}

Hammer, Ø., 2018. PAST. Paleontological Statistics. Version 3.20. Reference manual. PAST. Paleontological Statistics. Version 2.07. Reference Manual, (1999), 205.

https://doi.org/10.1016/j.bcp.2008.0 $\underline{5.025}$

Martin, R., \& Saller, K., 1957. Lehrbuch der Anthropologie: in systematischer Darstellung mit besonderer Berücksichtigung der anthropologischen Methoden. Stuttgart: G. Fischer.

Puymerail, L., Ruff, C. B., Bondioli, L., Widianto, H., Trinkaus, E. and Macchiarelli, R., 2012. Structural analysis of the Kresna 11 Homo erectus femoral shaft (Sangiran, Java). 
Journal of Human Evolution, 63(5), 741-749.

\section{https://doi.org/10.1016/j.jhevol.201} 2.08 .003

Rahmat, K. D., 2016. Posisi Stratigrafi Temuan Ekskavasi Situs Banjarejo, Grobogan. Jurnal Sangiran, 5, 103116.

Ruff, C. B., 2003. Long bone articular and diaphyseal structure in old world monkeys and apes. II: Estimation of body mass. American Journal of Physical Anthropology, 120(1), 16-37.

\section{https://doi.org/10.1002/ajpa.10118}

Ruff, C. B., Puymerail, L., Macchiarelli, R., Sipla, J. and Ciochon, R. L., 2015. Structure and composition of the Trinil femora: Functional and taxonomic implications. Journal of Human Evolution, 80, 147-158.

https://doi.org/10.1016/j.jhevol.201 $\underline{4.12 .004}$ van Bemmelen, R.W., 1949. The geology of Indonesia, Vol. IA: General Geology of Indonesia and Adjacent Archipelagoes. The Hague: Martinus Nijhoff.

White, T. D., \& Folkens, P. A., 2005. The human bone manual. Elsevier. Academic Press.

https://doi.org/10.1016/B978-0-12088467-4.50022-3

Widiyanta, W., 2018. Jenis, konteks stratigrafi dan lingkungan pengendapan temuan gajah purba di Situs Banjarejo. Jurnal Sangiran, 7, 63-78.

Widiyanta, W., 2020. Determinasi potensi geoarkeologi daerah Banjarejo dan sekitarnya. Jurnal Sangiran, 9, 40-56. 